\title{
The Cytotoxic Activity of the Total Alkaloids Isolated from Different Parts of Solanum pseudocapsicum
}

\author{
Pottekkad Vijayan, ${ }^{*}$ Preethi ViJayaraj, Prashanth Haranahalli Chandrappa SetTy, \\ Raghu Chandrashekhar Hariharpura, Ashok Godavarthi, Shrishailappa Badami, \\ Dhanaraj Sokkalingam Arumugam, and Suresh BhoJRAJ
}

J.S.S. College of Pharmacy; Rocklands, OOTACAMUND-643 001, Tamil Nadu, India.

Received September 4, 2003; accepted December 8, 2003

\begin{abstract}
The total alkaloid fractions of the methanolic extracts of the leaves, ripe fruits, roots, seeds and stem of Solanum pseudocapsicum were subjected to in-vitro cytotoxicity, short-term toxicity and long-term survival studies. All the five fractions exhibited potent activity. The total alkaloid fraction of leaves was found to be the most potent. The HT-29 cell line was the most sensitive to the fractions. The cytotoxic concentration $\left(\mathrm{CTC}_{50}\right)$ values for all these fractions ranged between $0.39-0.91,0.68-2.8,0.92-3.56,4.05-8.2,3.28-5.65$ and $0.95-5.55 \mu \mathrm{g} / \mathrm{ml}$, respectively for HT-29, RD-228, A-549, HEp-2, $B_{16} F_{10}$ and Vero cell lines. In short-term toxicity studies, the fractions showed $50 \%$ viability at $93-128 \mu \mathrm{g} / \mathrm{ml}$ for DLA cells and $141-189 \mu \mathrm{g} / \mathrm{ml}$ for human lymphocytes. In the long-term survival studies on the cell lines RD-228, HEp-2 and Vero, cells retained their regenerative capacities at concentrations below $8 \mu \mathrm{g} / \mathrm{ml}$. The total alkaloids of the plant, especially from the leaves merit further investigations to identify the active constituents in animal models.
\end{abstract}

Key words Solanum pseudocapsicum; total alkaloid; cytotoxicity; anti-tumor

Solanum pseudocapsicum (Family: Solanaceae) is an erect, much branched, non-spiny bushy shrub and is distributed in the gardens of Simla, Mussoorie, Dun Valley, The Nilgiris and other higher altitude places in India. The plant, (commonly called Jerusalem cherry), grows to about $0.6-1.2 \mathrm{~m}$ in height and has lanceolate or narrowly elliptical leaves. Its berries are green when unripe and yellow, scarlet or bright red when ripe. Their seeds are ovoid, compressed at one end and rounded at the other end and yellowish in color. ${ }^{1)}$ Its antimicrobial, ${ }^{2)}$ anti-viral, ${ }^{3)}$ anti-spasmodic ${ }^{4)}$ and anti-hypertensive ${ }^{4)}$ properties are known. The 50\% methanolic extract of the entire plant of Solanum pseudocapsicum has also been reported to possess cytotoxic activity in a preliminary study of Dhar et al. (1973). ${ }^{4)}$ Earlier studies in our laboratories showed significant in vitro cytotoxic and anti-tumor properties of the total alkaloid fraction of unripe fruits of Solanum pseudocapsicum. ${ }^{5}$ The present paper describes the in vitro cytotoxicity and anti-tumour properties on the total alkaloid fraction isolated from the methanolic extract of different parts of Solanum pseudocapsicum on malignant human rhabdomyosarcoma (RD-228) cells, human adenocarcinoma (HT29) cells, Caucasian male larynx epithelium carcinoma (HEp-2) cells, Human small cell lung cancer (A-549) cells, Mouse melanoma $\left(\mathrm{B}_{16} \mathrm{~F}_{10}\right)$ cells and normal African green monkey kidney (Vero) cells, Dalton's lymphoma ascites (DLA) cells and freshly isolated human lymphocytes.

\section{MATERIALS AND METHODS}

Plant Material and Isolation of Total Alkaloids The shrub Solanum pseudocapsicum was collected from the grounds in and around Government Arts College, Ootacamund, India, during July 2000 and authenticated by Survey of Medicinal Plants and Collection Unit, Ootacamund, India (Voucher No: 7345$)$. The leaves $(240 \mathrm{~g})$, ripe fruits $(255 \mathrm{~g})$, roots $(200 \mathrm{~g})$, seeds $(180 \mathrm{~g})$ and stems $(175 \mathrm{~g})$ were powdered and extracted in Soxhlet extractor using methanol for 18-
$20 \mathrm{~h}$. The extract was then concentrated to dryness under reduced pressure and controlled temperature. The total alkaloid fractions were isolated from the leaves $(0.192 \%)$, ripe fruits $(0.023 \%)$, roots $(0.157 \%)$, seeds $(0.148 \%)$ and stems $(0.092 \%)$, respectively following a conventional procedure. $\left.{ }^{6}\right)$ Each of the total alkaloid fractions was then dissolved in dimethyl sulphoxide (DMSO) separately and the volume was made upto $10 \mathrm{ml}$ with DMEM/RPMI-1640 medium to obtain a stock solution of $1 \mathrm{mg} / \mathrm{ml}$ concentration, sterilized by filtration and stored at $-20^{\circ} \mathrm{C}$ till use.

Cell Lines and Culture Medium HEp-2, HT-29, RD$228, \mathrm{~B}_{16} \mathrm{~F}_{10}, \mathrm{~A}-549$ and Vero cell cultures used in these experiments were obtained from National Centre for Cell Science, Pune, Pasteur Institute of India, Coonoor and Christian Medical College, Vellore, India. Stock cells of these cell lines were cultured in RPMI-1640 or DMEM supplemented with $10 \%$ inactivated sheep serum, penicillin $(100 \mathrm{IU} / \mathrm{ml})$, streptomycin $(100 \mu \mathrm{g} / \mathrm{ml})$ and amphoterecin-B $(5 \mu \mathrm{g} / \mathrm{ml})$ in a humidified atmosphere of $5 \% \mathrm{CO}_{2}$ at $37^{\circ} \mathrm{C}$ until confluent. The cells were dissociated with $0.2 \%$ trypsin, $0.02 \%$ EDTA in phosphate buffer saline solution. The stock cultures were grown in $25 \mathrm{~cm}^{2}$ tissue culture flasks and all cytotoxicity experiments were carried out in 96 well microtitre plates (Tarsons India Pvt. Ltd., Kolkata, India). DLA cells were obtained from Amala Cancer Institute, Trissur, India. DLA cells used were maintained in Swiss albino mice. Lymphocytes were isolated from an $\mathrm{O}+$ ve blood group healthy volunteer using histopaque. Studies for clonal growth were carried out in 24 well microtitre plates (Tarsons India Pvt. Ltd., Kolkata, India).

Cytotoxic Assay Cell lines in exponential growth phase were washed, trypsinized and re-suspended in complete culture media. Cells were plated at 10000 cells/well in 96 well microtitre plate and incubated for $24 \mathrm{~h}$ during which a partial monolayer forms. The cells were then exposed to various concentrations of the total alkaloid fractions in quadruplicate. Control wells received only maintenance medium. 
Table 1. Cytotoxic of the Total Alkaloid Fraction of Different Parts of Solanum pseudocapsicum on HEp-2, HT-29, RD-228, $\mathrm{B}_{16} \mathrm{~F}_{10}$, A-549 and Vero Cell Lines

\begin{tabular}{|c|c|c|c|c|c|c|c|c|c|c|c|c|c|}
\hline \multirow{3}{*}{$\begin{array}{l}\text { S1. } \\
\text { No. }\end{array}$} & \multirow{3}{*}{$\begin{array}{c}\text { Total } \\
\text { alkaloid } \\
\text { fraction }\end{array}$} & \multicolumn{12}{|c|}{ Cytotoxic concentration $\left.^{a}\right)\left(\mathrm{CTC}_{50}\right)(\mu \mathrm{g} / \mathrm{ml})$} \\
\hline & & \multicolumn{2}{|c|}{ HEp-2 } & \multicolumn{2}{|c|}{ HT-29 } & \multicolumn{2}{|c|}{ RD-228 } & \multicolumn{2}{|c|}{$\mathrm{B}_{16} \mathrm{~F}_{10}$} & \multicolumn{2}{|c|}{ A-549 } & \multicolumn{2}{|c|}{ Vero } \\
\hline & & MTT & SRB & MTT & SRB & MTT & SRB & MTT & SRB & MTT & SRB & MTT & SRB \\
\hline 1. & Leaves & $4.05 \pm 0.2$ & $7.5 \pm 0.3$ & ND & $0.39 \pm 0.02$ & $0.68 \pm 0.03$ & $0.82 \pm 0.03$ & $3.28 \pm 0.18$ & $3.55 \pm 0.2$ & $0.92 \pm 0.04$ & $1.05 \pm 0.04$ & $0.95 \pm 0.03$ & $2.58 \pm 0.12$ \\
\hline 2. & Ripe fruits & $6.4 \pm 0.3$ & $6.8 \pm 0.28$ & ND & $0.47 \pm 0.02$ & $0.97 \pm 0.04$ & $1.6 \pm 0.04$ & $5.26 \pm 0.26$ & $5.65 \pm 0.3$ & $2.26 \pm 0.1$ & $3.12 \pm 0.17$ & $2.6 \pm 0.1$ & $3.45 \pm 0.2$ \\
\hline 3. & Roots & $6.2 \pm 0.31$ & $8.2 \pm 0.32$ & ND & $0.91 \pm 0.04$ & $1.8 \pm 0.08$ & $2.8 \pm 0.12$ & $3.32 \pm 0.13$ & $4.24 \pm 0.16$ & $2.14 \pm 0.09$ & $3.09 \pm 0.1$ & $5.2 \pm 0.22$ & $5.55 \pm 0.21$ \\
\hline 4. & Seeds & $6.6 \pm 0.32$ & $7.6 \pm 0.31$ & ND & $0.62 \pm 0.02$ & $2.0 \pm 0.08$ & $2.2 \pm 0.07$ & $4.35 \pm 0.13$ & $4.85 \pm 0.2$ & $3.56 \pm 0.12$ & $3.38 \pm 0.1$ & $5.2 \pm 0.18$ & $4.8 \pm 0.13$ \\
\hline 5. & Stem & $4.03 \pm 0.16$ & $6.3 \pm 0.21$ & ND & $0.43 \pm 0.01$ & $0.98 \pm 0.02$ & $1.10 \pm 0.01$ & $3.65 \pm 0.12$ & $4.05 \pm 0.21$ & $2.84 \pm 0.12$ & $3.16 \pm 0.19$ & $2.35 \pm 0.09$ & $3.5 \pm 0.13$ \\
\hline
\end{tabular}

a) Average of 3 independent determinations, 4 replicates, values are mean $\mathrm{CTC}_{50} \pm \mathrm{S} . \mathrm{E}$., $\mathrm{ND}=$ not done.

The plates were incubated at $37^{\circ} \mathrm{C}$ in a humidified incubator with $5 \% \mathrm{CO}_{2}$ for a period of $72 \mathrm{~h}$. Morphological changes of drug treated cells were examined using an inverted microscope at different time intervals and compared with the cells serving as control. At the end of $72 \mathrm{~h}$, cellular viability was determined by using MTT $^{7)}$ and SRB assays. ${ }^{8)}$

Short-Term Toxicity Studies These studies were carried out on DLA cells and freshly isolated lymphocytes ${ }^{9)}$ using Trypan blue dye exclusion technique. ${ }^{10)}$

Long-Term Survival Studies A series of cultures were prepared in $25 \mathrm{~cm}^{2}$ tissue culture flasks (Tarsons India Pvt. Ltd., Kolkata, India), three for each concentration and three controls by seeding $5 \times 10^{4}$ cells $/ \mathrm{ml}$ and incubated for $48 \mathrm{~h}$. Growth medium was then decanted and cultures were exposed to test agents, which have been diluted to 5 fold $(200 \mu \mathrm{g} / \mathrm{ml}$ to $1.6 \mu \mathrm{g} / \mathrm{ml})$ and incubated at $37^{\circ} \mathrm{C}$ for a period of $2 \mathrm{~h}$. The cultures were then washed, trypsinized and seeded at densities $(5000$ cells $/ \mathrm{ml})$ for clonal growth in 24 well microtitre plates in growth medium. Control groups received complete growth medium throughout the study. Cultures were incubated until colonies formed. The colonies were fixed and stained with $0.5 \%$ crystal violet in absolute ethanol. Colonies containing more than 32 cells were considered to have retained their regenerative capacity. ${ }^{10)}$

\section{RESULTS AND DISCUSSION}

The cytotoxic effect of the total alkaloid fraction of the methanolic extracts of various parts of Solanum pseudocapsicum against different cell lines is shown in Table 1. Among the five different total alkaloid fractions, the fraction from the leaves was found to be the most potent in all the cell lines. The $\mathrm{CTC}_{50}$ values for the total alkaloid fraction of leaves were found to be $0.39 \mu \mathrm{g} / \mathrm{ml}$ for HT-29, $0.68-0.82 \mu \mathrm{g} / \mathrm{ml}$ for $\mathrm{RD}-228,0.92-1.05 \mu \mathrm{g} / \mathrm{ml}$ for A-549, $0.95-2.58 \mu \mathrm{g} / \mathrm{ml}$ for Vero, $3.28-3.55 \mu \mathrm{g} / \mathrm{ml}$ for B16F10 and $4.05-7.5 \mu \mathrm{g} / \mathrm{ml}$ for HEp-2. HEp-2 cell line was found to be most sensitive to the total alkaloid fraction from the stem, which showed a $\mathrm{CTC}_{50}$ value of $4.03-6.3 \mu \mathrm{g} / \mathrm{ml}$. Among the six cell lines tested for cytotoxicity, HT-29 was found to be the most susceptible. The $\mathrm{CTC}_{50}$ values for all the five fractions ranged between $0.39-0.91 \mu \mathrm{g} / \mathrm{ml}$ for HT-29. RD-228 was found to be the next sensitive cell line with $\mathrm{CTC}_{50}$ values ranging between $0.68-2.8 \mu \mathrm{g} / \mathrm{ml}$. The $\mathrm{CTC}_{50}$ values for A-549, Vero, $\mathrm{B}_{16} \mathrm{~F}_{10}$ and HEp-2 were between $0.92-3.56,0.95-5.55,3.28-$ 5.65 and $4.05-8.2 \mu \mathrm{g} / \mathrm{ml}$, respectively.
Table 2. Short-Term Toxicity Studies of the Total Alkaloid Fractions of Different Parts of Solanum pseudocapsicum on DLA Cells and Lymphocytes after $3 \mathrm{~h}$ of Exposure

\begin{tabular}{cccc}
\hline \hline \multirow{2}{*}{$\begin{array}{c}\text { Sl. } \\
\text { No. }\end{array}$} & Total alkaloid & \multicolumn{2}{c}{ Cytotoxic concentration $^{a)}\left(\mathrm{CTC}_{50}\right) \mu \mathrm{g} / \mathrm{ml}$} \\
\cline { 3 - 4 } & fraction & DLA cells & Lymphocytes \\
\hline 1. & Leaves & $128 \pm 3.38$ & $141 \pm 3.50$ \\
2. & Ripe fruits & $105 \pm 3.18$ & $189 \pm 2.70$ \\
3. & Roots & $108 \pm 3.56$ & $156 \pm 3.04$ \\
4. & Seeds & $115 \pm 3.06$ & $168 \pm 3.12$ \\
5. & Stem & $93 \pm 3.56$ & $170 \pm 2.82$ \\
\hline
\end{tabular}

a) Average of 3 independent determinations, 6 replicates, values are mean $\mathrm{CTC}_{50} \pm$ S.E.

In the short-term anti-tumor studies, using DLA cells, treatment with the total alkaloid fractions resulted in 50\% viability in the concentration range of $93-128 \mu \mathrm{g} / \mathrm{ml}$. Among the five fractions, the stem fraction was found to be most active. A similar study on freshly isolated lymphocytes revealed $\mathrm{CTC}_{50}$ values between $141-189 \mu \mathrm{g} / \mathrm{ml}$. The total alkaloid fraction of the leaves was found to be the most potent with a $\mathrm{CTC}_{50}$ value of $141 \mu \mathrm{g} / \mathrm{ml}$.

In long-term survival studies carried out with RD-228, HEp-2 and Vero cells, the cells retained their regenerative capacities at concentrations below $8 \mu \mathrm{g} / \mathrm{ml}$. Among the three cell lines tested for this activity, RD-228 cell line was found to be more sensitive to the total alkaloid fractions.

Plants with potential anti-cancer properties are known in the literature. Catharanthus roseus, Taxus brevifolia and Podophyllum species are the most successful higher plant materials used in cancer chemotherapy. ${ }^{11)}$ Several plants belonging to the genus Solanum exhibited strong cytotoxic and anti-tumor properties. Solanum trilobatum, ${ }^{12)}$ Solanum incanum, ${ }^{13)}$ Solanum capsicastrum, ${ }^{14)}$ Solanum gnera ${ }^{15)}$ Solanum indicum, ${ }^{16)}$ Solanum sodomaeum, ${ }^{17)}$ Solanum nigrum ${ }^{7}$ are a few plants with potential activities. In the present study, the total alkaloid fraction of different parts of Solanum pseudocapsicum exhibited potent cytotoxic and anti-tumor properties. The cytotoxic studies of these fractions were carried out in six different cell lines using MTT and SRB assays. Among the five total alkaloid fractions, the leaves fraction was the most potent. The maximum cytotoxicity was observed against human adenocarcinoma (HT-29) cells. The human rhabdomyosarcoma (RD-229) and human small cell lung cancer (A-549) were also susceptible to the 
Table 3. Long-Term Test for Survival Method Studies of the Total Alkaloid Fractions of Different Parts of Solanum pseudocapsicum on HEp-2, RD-228 and Vero Cell Lines

\begin{tabular}{|c|c|c|c|c|c|c|c|c|c|c|c|c|c|}
\hline \multirow{3}{*}{ S1. No. } & \multirow{3}{*}{$\begin{array}{c}\text { Total } \\
\text { alkaloid } \\
\text { fraction of }\end{array}$} & \multicolumn{12}{|c|}{ Number of cells per colony at different concentrations in cell lines ${ }^{a, b}$} \\
\hline & & \multicolumn{3}{|c|}{$200 \mu \mathrm{g} / \mathrm{ml}$} & \multicolumn{3}{|c|}{$40 \mu \mathrm{g} / \mathrm{ml}$} & \multicolumn{3}{|c|}{$8 \mu \mathrm{g} / \mathrm{ml}$} & \multicolumn{3}{|c|}{$1.6 \mu \mathrm{g} / \mathrm{ml}$} \\
\hline & & HEp-2 & RD-228 & Vero & HEp-2 & RD-228 & Vero & HEp-2 & RD-228 & Vero & HEp-2 & RD-228 & Vero \\
\hline 1 & Leaves & 0 & 0 & 0 & 16 & 6 & 0 & 43 & 35 & $>50$ & $>50$ & $>50$ & $>50$ \\
\hline 2 & Ripe fruits & 0 & 0 & 0 & 8 & 6 & 8 & $>50$ & 36 & 48 & $>50$ & $>50$ & $>50$ \\
\hline 3 & Roots & 0 & 0 & 0 & 10 & 8 & 4 & 48 & 38 & 42 & $>50$ & $>50$ & $>50$ \\
\hline 4 & Seeds & 0 & 0 & 0 & 5 & 9 & 5 & $>50$ & 35 & 50 & $>50$ & $>50$ & $>50$ \\
\hline 5 & Stems & 0 & 0 & 0 & 12 & 7 & 8 & 41 & 33 & 48 & $>50$ & $>50$ & $>50$ \\
\hline
\end{tabular}

a) Average of 3 determinations, 4 replicates. b) All the cell lines in control group showed $>50$ cells/colony.

total alkaloid fraction of the leaves. In the short-term toxicity studies using DLA cells and lymphocytes, the $\mathrm{CTC}_{50}$ values ranged between $93-128 \mu \mathrm{g} / \mathrm{ml}$ and $141-189 \mu \mathrm{g} / \mathrm{ml}$, respectively. Long-term survival studies showed that the cells when treated with the total alkaloid fractions retained their proliferative capacities at concentrations below $8 \mu \mathrm{g} / \mathrm{ml}$.

All these studies confirms the cytotoxic and anti-tumor nature of the plant Solanum pseudocapsicum. Similar results were obtained in earlier studies carried out in our laboratories using the total alkaloid fraction of unripe fruits of Solanum pseudocapsicum. ${ }^{5)}$ Reports indicate that steroidal alkaloids from Solanum species possess strong cytotoxic and anti-tumor properties. Solamargine from Solanum nigrum, ${ }^{7)}$ incanumine from Solanum incanum, ${ }^{13)}$ glycoalkaloids from Solanum sodamaeum ${ }^{17)}$ and several other steroidal alkaloidal glycosides, ${ }^{15)}$ are known to possess these properties.

Phytochemical tests indicated the steroidal nature of the total alkaloid of Solanum pseudocapsicum. Several steroidal alkaloids including solanocapsine, solacasine, solacapine, episolacapine, isosolacapine and $o$-methyl solanocapsine have been isolated from the arboreal part of the plant. ${ }^{18)}$ Hence, the observed cytotoxic and anti-tumor principles may also be due to the presence of steroidal alkaloids. In conclusion, the total alkaloid fractions of the plant Solanum pseudocapsicum merit further investigations to identify the active principles responsible for the anti-tumor properties and to further prove the activity in animal models.

\section{REFERENCES}

1) Anonymous, “The Wealth of India," Vol. 9, CSIR, New Delhi, 1989, pp. 392-393.

2) Mitscher L. A., Juvakar J. V., Beal J. L., Experientia, 32, 415 (1976).

3) Van Den Berghe D. A., Ieven M., Mertens F., Vlietinck A. J., Lammens E., J. Nat. Prod., 11, 463-467 (1978).

4) Dhar M. L., Dhar M. M., Dhawan B. N., Mehrotra B. N., Srimal R. C., Tandon J. S., Indian J. Exp. Biol., 11, 43-45 (1973).

5) Vijayan P., Vinod Kumar S., Dhanaraj S. A., Shrishailappa Badami, Suresh B., Pharm. Biol., 40, 456-460 (2002).

6) Trease G. W., Evans W. C., "Pharmacognosy," 11th ed., Bailliere Tindall, London, 1978, p. 530.

7) $\mathrm{Hu} \mathrm{K.,} \mathrm{Kobayashi} \mathrm{H.,} \mathrm{Dong} \mathrm{A.,} \mathrm{Jing} \mathrm{Y.,} \mathrm{Iwasaki} \mathrm{S.,} \mathrm{Yao} \mathrm{X.,} \mathrm{Planta}$ Med., 65, 35-38 (1999).

8) Skehan P., Storeng R., Scudiero D., Monks A., McMahon J., Vistica D., Warren J. T., Bokesch H., Kenney S., Boyd M. R., J. Natl. Cancer Inst., 82, 1107-1112 (1990).

9) Unnikrishnan M. C., Kuttan R., Nutrition \& Cancer, 11, 251-257 (1988).

10) Freshney R. I., "Culture of Animal Cells: A Manual of Basic Technique," 4th ed., Wiley-Liss, New York, 2000, p. 323 \& 331.

11) Dahamukar S. A., Kulkarni R. L., Rege N. N., Indian J. Pharamacol., 32, S81-S118 (2000).

12) Mohanan P. V., Devi K. S., Cancer Lett., 10, 71-76 (1996).

13) Hsu S. H., Tsai T. R., Lin C. N., Yen M. H., Kuo K. W., Biochem. Biophys. Res. Commun., 229, $1-5$ (1996).

14) Gan K. H., Lin C. N., Won S. J., J. Nat. Prod., 56, 15-21 (1993).

15) Nakamura T., Komori C., Lee Y., Hashimoto F., Yahara S., Nohara T., Ejima A., Biol. Pharm. Bull., 19, 564-566 (1996).

16) Chiang H. C., Tseng T. H., Wang C. J., Chen C. F., Kan W. S., Anticancer Res., 11, 1911-1918 (1991).

17) Cham B. E., Meares H. M., Cancer Lett., 36, 111-118 (1987).

18) Chakravarty A. K., Das B., Ali E., Pakrashi S. C., J. Chem. Soc. Perkin Trans 1, 1984, 467-474 (1984). 